DOI https://doi.org/10.30525/978-9934-26-007-0-21

\title{
МІЖНАРОДНИЙ ДОСВІД ЗАПОБІГАННЯ ТЕРОРИСТИЧНИМ АКТАМ У ВЕЛИКИХ МІСТАХ
}

\section{Стукаліна О. В., Кулик Л. М.}

\section{ВСТУП}

Важливу роль у процесі модернізації та інтеграції заходів запобігання терористичним актам у великих містах України відіграє міжнародний досвід запобіжної діяльності щодо такого виду кримінальних правопорушень. На сучасному етапі більшість високорозвинених країн світу мають значні досягнення у сфері запобігання терористичним актам у великих містах. Держави зі стабільною правовою системою спрямовують значні ресурси для пошуку нових та адаптованих до реалій сьогодення підходів до запобігання терористичним актам. Аналіз засад і механізмів дії зарубіжних систем запобігання надає можливість розробки рекомендацій для вітчизняної системи запобігання терористичним актам у великих містах.

Найбільш актуальним і дієвим, на нашу думку, є досвід таких країн, як Сполучені Штати Америки та держав-членів Європейського Союзу (далі ЄС). Ці країни мають стабільну правову систему, достатньо високу економічну розвиненість і вагому базу напрацювань у сфері запобігання терористичним актам у великих містах. Незважаючи на те, що кожна із зазначених держав має власні традиції та звичаї, різний історичний досвід, між собою вони подібні використанням вдалих інструментів і механізмів, які покликані максимально якісно та цілісно ліквідувати терористичні акти в інтересах суспільства, держави та світової спільноти, здійснивши перехід від моделі протидії до суспільно-орієнтованої моделі - запобігання.

Офіційно опубліковані статистичні дані глобального рейтингу індексу терористичних актів «The Global Terrorism Index», розробленого міжнародною групою експертів Інституту економіки та миру Сіднейського університету, демонструють те, що в 2016 р. серед 162 країн світу Франція займає 29 місце з коефіцієнтом терористичної активності - 5,603, одразу ж поряд із Францією у рейтингу розташувалися Велика Британія та США, котрі посіли 34 та 36 місця, індекс яких сягає 5,08 та 4,877 відповідно, натомість Німеччина із кращим результатом зайняла 41 місце 3 коефіцієнтом 4,308. Нагадаємо, що Україна за даними рейтингу зайняла 11 місце 3 індексом тероризму 7,132, у чому простежується значний відрив української держави у гіршу сторону на відміну від вище представлених країн, ситуація в яких більш помірна ${ }^{1}$.

\footnotetext{
${ }^{1}$ Global Terrorism Index 2016. Institute for Economics \& Peace. URL: https://www.economicsandpeace.org/ wp/content/uploads/2016/11/Global-Terrorism-Index-2016.2.pdf (дата звернення: 30.10.2020).
} 
Порівняння показників 2016 з 2019 рр. демонструють те, що за три роки стан США та Великої Британії дещо похитнувся, так, позиції поширення терористичної загрози США із 36 місця піднялися на 22 зі зміною в індексі $(+0,8)$; Велика Британія з 34 місця піднялася на 28 зі зміною індексу $(+0,3)$. Натомість країни, які входять до складу Свропейського Союзу - Франція та Німеччина, покращили свої позиції у рейтингу, Франція із 29 місця опустилася на 36 зі зміною в індексі $(-0,6)$, а Німеччина із 41 місця перейшла на 44 зі зміною в індексі $(-0,05)^{2}$.

Кількісні показники терористичних проявів і задовільне місце США, Франції, Великої Британії та Німеччини у світовому рейтингу індексу терористичних актів вказують на те, що зазначені країни уміло протидіють терористичним актам, тому їхні теоретичні та практичні знання є корисним підгрунтям для впровадження нових заходів у вітчизняну систему запобігання терористичним актам у великих містах, а також для вдосконалення і модернізації вже наявних заходів.

\section{1. Досвід США у запобіганні терористичним актам у великих містах}

Безсумнівно, однією 3 високорозвинених країн сучасного світу $\epsilon$ Сполучені Штати Америки. На тлі різноманітного ландшафту терористичних загроз у світі США залишаються світовим лідером у процесі запобігання та протидії терористичним актам. Ця держава зарекомендувала себе 3 найкращого боку, проводячи багаторічну протидію терористичній діяльності, підготовку висококласних спеціалістів для запобігання i протидії тероризму, а також активне міжнародне співробітництво з іншими країнами, мобілізуючи та наставляючи своїх союзників i партнерів у протидії цьому суспільно небезпечному явищу.

За офіційними американськими статистичними джерелами, в період із 1994 по 2020 рік на території США терористами було вчинено 893 терористичні акти. Наукові співробітники Центру стратегічних і міжнародних досліджень США з'ясували ідеологію терористів, які вчинили вище представлені акти. Так, вони виокремили п'ять категорій спрямованості терактів: етнічно-націоналістичну, ліву, релігійну, праву та інші (включаючи мотиви, що не належать до представлених категорій). За цей двадцятишестирічний період правими терористами було вчинено більшість від представленої кількості терактів, що налічує близько $57 \%, 25 \%$ від загальної кількості вчинено лівими терористами, 15\% -

\footnotetext{
${ }^{2}$ Global Terrorism Index 2019. Institute for Economics \& Peace. URL: https://www.economicsandpeace.org/ wp-content/uploads/2020/08/GTI-2019web.pdf (дата звернення: 30.10.2020).
} 
релігійними, близько $3 \%$ - терористами з етнічно-національною ідеологією та $0,7 \%$ - терористами, які мали інші мотиви ${ }^{3}$.

На думку американських аналітиків, наприкінці 2020 р. терористична загроза у США значно зросте через декілька факторів: президентські вибори та реакцію на кризу, пов'язану з поширенням інфекційної хвороби Covid-19. Представлені фактори не $\epsilon$ причиною тероризму взагалі та терористичних актів зокрема, але вони $\epsilon$ подіями, які можуть породжувати гнів і нетерпимість серед різних терористичних груп та організацій, що стане приводом для розповсюдження насильства у виді терактів як способу демонстрації своїх невдоволень. Стосовно фактору, пов'язаного 3 поширенням інфекційної хвороби Covid-19, то тут основними чинниками, які можуть збільшити ймовірність терористичних актів, є безробіття та спроби уряду закрити на карантин другорядні підприємства у відповідь на другу або третю хвилю розповсюдження хвороби. У березні 2020 р. один із терористів був убитий у перестрілці 3 агентами ФБР. Терорист потрапив у поле зору федеральних агентів у рамках моніторингу домашніх терористів, внаслідок чого ними було встановлено, що останній готував серію вибухів у лікарнях штату Miccypi, де лікувалися хворі 3 Covid- $19^{4}$. Терористи намагаються підірвати американські ідеали та діяльність уряду США, застосовуючи насильство та пропаганду для досягнення своїх злочинних цілей.

Наприкінці 2018 р. президент США затвердив Національну стратегію боротьби та запобігання тероризму, яка втілює в собі новий еволюційний підхід у процесі стабілізації рівня терористичних актів і знешкодження терористичної загрози в усьому світі та на теренах Америки. Як визначено у документі, ті стратегії, які не принесли очікуваних результатів, будуть виключені, а нові підходи, підтверджені досвідом, будуть реалізовані. Ця стратегія відрізняється від попередніх тим, що вона застосовує більш рухливий та експансивний підхід, який розглядає весь спектр терористичних загроз для США, включаючи зарубіжних ворогів та осіб, на яких вони прагнуть впливати та яких планують вербувати для вчинення насильства у США. Тобто центральна мета стратегії спрямована на захист американських свобод i непохитність у зобов'язанні перемогти всіх, хто застосовує насильство, намагаючись знищити, дестабілізувати чи погіршити стан суспільства ${ }^{5}$.

\footnotetext{
${ }^{3}$ The Escalating Terrorism Problem in the United States. Center for strategic \& International studies. 2020. URL: https://www.csis.org/analysis/escalating-terrorism-problem-united-states (дата звернення: 08.11.2020).

4 Tам само.

${ }^{5}$ National Strategy for Counterterrorism of the United States of America. URL: https://www.whitehouse.gov/ wp-content/uploads/2018/10/NSCT.pdf (дата звернення: 09.11.2020).
} 
Основні цілі та задачі, які ставлять перед собою США у процесі запобігання терористичним актам, спрямовані на: зменшення рівня нападів терористів на території штатів; розірвання фінансових, матеріальних i матеріально-технічних джерел сили та підтримки терористів; ліквідацію спроможності терористів вербувати людей і надихати на реалізацію терористичних цілей; посилення охорони кордонів; покращення діяльності правоохоронних органів; нездатність терористів придбати та використовувати зброю масового ураження; розширення кола партнерів із державного та приватного сектору, в т. ч. іноземних ${ }^{6}$.

У процесі розробки та реалізації заходів запобігання терористичним актам у США опираються на три принципи, серед яких активне партнерство; масштабність, гнучкість та адаптованість; готовність діяти. Перший принцип - активне партнерство, його сутність полягає в тому, що у процесі запобігання терористичним актам мають бути налагоджені партнерські відносини, які полягають в обміні розвідувальною й оперативною інформацією, а також у наданні допомоги та необхідних ресурсів. Другий принцип - масштабність, гнучкість та адаптованість - полягає в тому, що залежно від масштабу терористичної загрози компетентні суб'єкти обирають підходящий варіант запобігання, усі запобіжні заходи гнучкі та виконуються у міру необхідності для усунення повного спектру загроз, заходи безперервно функціонують, швидко змінюються та пристосовуються до виниклих обставин. Третій принцип - готовність діяти - полягає в тому, що, як тільки отримано інформацію про підготовку терористичного акту або виявлено наявну терористичну загрозу, компетентні суб'єкти об'єднують зусилля та націлюються на виконання рішучих заходів ${ }^{7}$.

Вдосконалюючи систему запобігання та протидії терористичним актам, американські органи влади дійшли того, що доцільно використовувати кожний доступний інструмент для перемоги над тероризмом у країні, за кордоном і на теренах кіберпростору. Американська запобіжна система в рамках попередження терористичних актів реалізується шляхом застосування військових і розвідувальних операцій за кордоном, дій правоохоронних органів, міжнародної співпраці та використання можливих фінансових інструментів. Першочергово зусилля були спрямовані на захист кордонів застосувавши більш суворий контроль заяв на в'їзд до країни, захист уразливих об'єктів інфраструктури від терористичних актів, а також на

\footnotetext{
${ }^{6}$ National Prevention Framework. Second Edition. URL: https://www.fema.gov/media-librarydata/ 146601720927983b/72d5959787995794c08/74095500b1/National_Prevention_Framework2nd.pdf (дата звернення: 10.11.2020).

7 Tам само. URL: https://www.fema.gov/medialibrarydata/146601720927983b72d5959787995794c08/ 74095500b1/National_Prevention72d5959787995794c08/74095500b1/National_Prevention_Framework2nd.pdf (дата звернення: 10.11.2020).
} 
використання нових технологій. Крім того, 3 урахуванням еволюційних терористичних загроз антитерористична стратегія США віддає перевагу невійськовим можливостям запобігання, серед яких викриття спроб вербування людей терористами, мінімізація терористичної пропаганди в Інтернеті та формування соціальної стійкості до тероризму ${ }^{8}$.

Головне місце у реалізації заходів запобігання терористичним актам у великих містах належить Федеральному Бюро Розслідувань (далі ФБР). У складі ФБР створено Відділ по боротьбі з тероризмом і Центр із відстеження терористичної активності. Діяльність ФБР із реалізації заходів запобігання терористичним актам багатогранна; попередньо готуючи модель протидії терористичним актам, вони успішно втілюють іiі у практиці. Серйозним викликом для ФБР $є$ наявні у країні терористичні загрози, на цій підставі ними розроблено широкомасштабну програму боротьби з тероризмом, яка базується на ретельних розслідуваннях припинення актів терористичної діяльності, міжвідомчому співробітництві й ефективному запобіганні ${ }^{9}$.

Співробітники ФБР значну увагу приділяють просвітницькій i профілактичній діяльності серед населення, застерігаючи людей захищати себе як у мережі, так і при особистій зустрічі, а також закликають одразу ж повідомляти про будь-яку підозрілу активність, із якою вони стикаються. Крім того, вони впевнені, що цілі запобігання можливо домогтися такими способами, як: по-перше, не забувати про своє оточення; по-друге, утримуватися від розголошення особистої інформації; по-третє, не забувати про принцип «Скажи що-небудь, якщо щось побачиш». Ізольований характер діяльності сучасних терористів ускладнює їх виявлення й усунення правоохоронними органами, тоді як сім'я або друзі можуть бути першими, хто помічає відповідну зміну у поведінці, яка може вказувати на те, що людина мобілізується до насильства та готується до вчинення терористичних актів ${ }^{10}$. У дійсності цей підхід приносить чимало успіхів, але, оскільки терористична загроза має динамічний характер, ФБР систематично вдосконалює й адаптує заходи запобігання терористичним актам, щоб і надалі забезпечувати найефективніше реагування на них ${ }^{11}$.

\footnotetext{
${ }^{8}$ National Strategy for Counterterrorism of the United States of America. URL: https://www.whitehouse.gov/ wp-content/uploads/2018/10/NSCT.pdf (дата звернення: 09.11.2020).

${ }^{9}$ Terrorism 2002-2005. U.S. Department of Justice Federal Bureau of Investigation. 2005. URL: https://www.fbi.gov/stats-services/publications/terrorism-2002-2005 (дата звернення: 10.11.2020).

${ }^{10}$ Інформація 3 офіційного сайту ФБР. URL: https://www.fbi.gov/investiga/te/terrorism (дата звернення: 10.11.2020).

${ }^{11}$ Мокляк В.В. Сучасний досвід США у сфері запобігання тероризму. Питання боротьби зі злочинністю. 2017. № 34. С. 219-229. URL: http://nbuv.gov.ua/UJRN/Pbzz_2017_34_20 (дата звернення: 10.11.2020).
} 
На рахунку агентів ФБР велика кількість яскравих прикладів вдалого застосування заходів запобігання терористичним актам у великих містах США, наведемо декілька 3 них. Так, співробітники ФБР заарештували гр. Р. за змову у підірвані об'єктів берегової охорони США у найбільшому місті штату Вашингтон - Беллінгемі. Як стало відомо під час розслідування, гр. Р. проголошував себе анархістом, намагався спровокувати революцію у США й обговорював напад на кілька військових об'єктів. Запобігти реалізації планів гр. Р., націлених на вчинення терористичного акту, співробітникам ФБР вдалося, заарештувавши останнього після того, як він вів переговори 3 таємним агентом ФБР про придбання компонентів вибухових пристроїв. Ще одним прикладом успішного застосування заходів запобігання терористичним актам у великих містах США: гр. Д. у місті Маямі штату Флорида запланував серію нападів на клініки, які проводять аборти. Гр. Д. відкрито обговорював свої наміри щодо атак клінік, що займаються проведенням абортів, висловлював солідарність із екстремістами, котрі виступали проти абортів, а також зв'язувався з їхніми представниками. Визначивши потенційні цілі та конкретні часові межі вчинення терористичних актів, провів відеозйомку зазначених об'єктів, а також придбав через джерела ФБР усі необхідні предмети для проведення терактів, у т. ч. ємності з бензином і пропаном, проте був заарештований, так і не реалізувавши свій терористичний намір ${ }^{12}$.

Отже, ФБР наділене широким колом повноважень, достатнім матеріальнотехнічним забезпеченням, великим штатом професійних агентів, значним надбанням у розвідувальній і оперативній діяльності, завдяки цьому їм вдається якісно та рішучо попереджати терористичні акти у великих містах США. Антитерористична діяльність ФБР багатостороння, агенти не чекають настання терористичного акту, щоб потім шукати причини його вчинення, навпаки, вони завчасно й оперативно беруться за інформацію, яка може свідчити про можливий терористичний акт. Тому використання досвіду ФБР у сфері запобігання терористичним актам у великих містах стане підгрунтям для вдосконалення національної системи антитерористичних заходів в Україні.

Не менш значне місце у запобіганні терористичним актам у великих містах США посідають фізичні особи, громадські організації, релігійні спільноти та представники приватної діяльності. Кожен із них у міру своїх можливостей сприяє попередженню терористичних актів на території держави. Фізичні особи, громадські організації, релігійні спільноти та представники приватної діяльності допомагають державним органам

\footnotetext{
12 Terrorism 2002-2005. U.S. Department of Justice Federal Bureau of Investigation. 2005. URL: https://www.fbi.gov/stats-services/publications/terrorism-2002-2005 (дата звернення: 10.11.2020).
} 
у процесі запобігання шляхом виявлення та інформування правоохоронних органів про підготовку терористичного акту або настання потенційної терористичної загрози, які переважно локалізуються в Інтернеті, де терористи мають віртуальний доступ до людей, які проживають у США. У цьому аспекті варто зазначити, що у більшості членів суспільства сформована індивідуальна пильність і правова свідомість, що допомагає правоохоронним органам у реалізації профілактичних заходів ${ }^{13}$.

Таким чином, національна система запобігання терористичним актам у великих містах США зарекомендувала себе з позитивної сторони. Як уже зазначалося, заходи запобігання терористичним актам у великих містах США побудовані на трьох принципах - активному партнерстві; масштабності, гнучкості йі адаптованості; готовності діяти. Система запобігання терористичним актам у США характеризується вагомою законодавчою базою, яка повністю забезпечує функціонування державних органів у цій сфері; широким спектром суб'єктів запобігання терористичним актам у великих містах, діяльність яких оперативна та скоординована між собою; активною участю фізичних осіб, громадських організацій, релігійних спільнот і представників приватної діяльності у попередженні злочинних намірів терористів; розгалуженою низкою заходів, серед яких - захист кордонів, захист уразливих об'єктів інфраструктури, викриття спроб вербування людей терористами у терористичну діяльність, мінімізація терористичної пропаганди через ЗМI та Інтернет, міжнародне співробітництво та формування соціальної стійкості до терористичного акту.

Для України використання досвіду США у запобіганні терористичним актам у великих містах повинно сприяти посиленню антитерористичної складової частини громадської безпеки. Ми переконані, що впровадження антитерористичного досвіду США в українську запобіжну систему буде сприяти: якісному запобіганню терористичним актам; налагодженій роботі суб'єктів, покликаних запобігати терактам, їх взаємодії між собою; унеможливленню застосування зброї масового ураження, в т. ч. вдосконаленої зброї під час вчинення терористичних актів; забороні надавати допомогу терористам; забороні фінансувати терористичні акти; перешкоджанню терористам у контролюванні регіонів і їх міст; укріпленню громадянської позиції нетерпимості до готування та вчинення терактів; укріпленню партнерських відносин з іншими країнами.

\footnotetext{
${ }^{13}$ National Prevention Framework. Second Edition. URL: https://www.fema.gov/media-librarydata/ 146601720927983b72d5959787995794c08/74095500b1/National_Prevention_Framework2nd.pdf звернення: 10.11.2020).
} 


\section{2. Досвід держав-членів Свропейського Союзу у запобіганні терористичним актам}

У світлі того, що українська держава обрала курс на євроінтеграцію та має намір стати членом Свропейського Союзу, варто побороти перепони, які стоять на шляху до членства, однією з таких $є$ і терористичні акти. Держави-члени СС, зокрема Франція, Велика Британія і Німеччина, ведуть активну боротьбу за зміцнення громадської безпеки та правопорядку шляхом мінімізації рівня терористичних актів. Для цих країн демократичні цінності, дотримання прав людини, захист суспільства й окремих громадян від злочинних посягань, у т. ч. терористичних, є основним критерієм функціонування механізмів державного управління.

За умов значної терористичної загрози у Європі кожна $з$ держав тією чи іншою мірою зазнавала шкоди від терористичних актів. За цих обставин правоохоронні органи модернізували та встановили міцну систему запобігання терористичним актам у країнах загалом, а особливо у великих містах, що полягає у застосуванні досконалих запобіжних заходів. Тому для вдосконалення вітчизняної системи запобігання терористичним актам у великих містах досвід держав-членів СС у подоланні цього суспільно небезпечного явища відіграє значну роль. 3 огляду на те, що Україна прагне членства в СС, механізми функціонування органів державної влади, в т. ч. правоохоронних, мають відповідати міжнародним стандартам.

За офіційними статистичними даними, опублікованими у звіті про тероризм на території ЄС, у період із 2015 по 2019 рр. спостерігається покращення терористичної ситуації в державах-членах Європейського Союзу, яка характеризується позитивною динамікою показників. Зокрема, тільки у 2015 р. зареєстровано 211 терористичних актів, у 2016 р. - 142, у 2017 р. їх кількість становила 205, у 2018 р. - 128, тоді як у 2019 р. було зареєстровано 119 терористичних актів, тобто порівняння статистичних даних, зареєстрованих у Європейському Союзі з 2015 по 2019 рр., свідчать про стрімке зниження терористичних актів майже на 44\%. Практично від кожного терористичного акту тією чи іншою мірою страждають члени суспільства, зараз терористи прагнуть спричиняти масову загибель людей, використовуючи більш зухвалі методи. Позитивною тенденцією до зниження характеризується рівень жертв, які загинули від терористичних актів у країнах-членах $\mathrm{CC}$, так, у 2015 р. від терористичних актів загинула 151 особа, натомість у 2019 р. їх було 10, тобто протягом чотирьох років відбулося значне зниження кількості загиблих жертв від терористичних актів на $93 \%{ }^{14}$.

\footnotetext{
${ }^{14}$ Terrorism in Europe. Statistics \& Facts. URL: https://www.statista.com/topics/3788/terrorism-in-europe (дата звернення: 01.11.2020).
} 
За період 2015-2019 рр. терористичні акти поширилися майже усіма країнами-членами $\mathrm{CC}$, у досліджуваних державах зафіксовано такий розподіл: у Великій Британії у 2015 р. було зареєстровано 114 терористичних актів, тоді як у 2016 р. їх кількість становила 105 (-8\%), у 2017 р. - 122 (+7\%), у 2018 р. - 60 (-47\%), а у 2019 р.- 64 (-44\%) терористичних актів, тобто протягом 2015-2019 pр. у Великій Британії відбулося зниження рівня терористичних актів на 44\%; у Франції у 2015 р. було зареєстровано 37 терористичних актів, у 2016 р. - 26 (-30\%), у 2017 р. - 41 (+11\%), у 2018 р. - 30 (-19\%), натомість у 2019 р. - 7 (-81\%) терористичних актів; у Німеччині у 2015 р. було зареєстровано 65 терористичних актів, у 2016 р. $44(-32 \%)$, у 2017 р. - 27 (-58\%), у 2018 р. - 2 (-97\%), тоді як у 2019 р. зафіксовано 3 (-95\%), тобто 32015 до 2019 рр. у Німеччині рівень терористичних актів знизився на 95\%; в Іспанії у 2015 р. зареєстровано 1 терористичний акт, у 2016 p. - 3, у 2017 p. - 4, у 2018 р. - 11 терактів, а у 2019 р. їх кількість налічувала 3 терористичні акти, тобто відбулося зниження рівня терористичних актів на $67 \%{ }^{15}$. Отже, за середніми показниками терористичної ураженості Велика Британія, Франція, Німеччина та Іспанія знаходяться в одній кримінологічній групі із вираженими тенденціями покращення терористичної ситуації, ці країни характеризуються позитивною динамікою протягом зазначеного часового проміжку, що свідчить про суттєві досягнення у розвитку та вдосконалення системи запобігання терористич-ним актам як на загальнодержавному, так i на місцевому рівнях.

Європейський Союз є територією зростаючої відкритості та взаємозалежності, у якій внутрішні та зовнішні аспекти безпеки нерозривно пов'язані між собою. Терористи часто зловживають цими суспільними благами для досягнення своїх цілей, тому на рівні Євросоюзу налагоджений процес координованих, колективних дій, спрямованих на запобігання терористичним актам. Так, у 2005 р. у ЄС розроблено цілісну контртерористичну стратегію, яка зобов'язала кожну державу, котра $є$ членом Союзу, націлитися на глобальне викорінення тероризму, створюючи для своїх громадян безпечну зону свободи та миру. 3 цією метою було запроваджено цілий комплекс необхідних заходів, серед яких: попередження звернення людей до терористичної діяльності, тобто запобігання появі майбутніх поколінь терористів; захист громадян i критично важливої інфраструктури за рахунок зниження їх уразливості від актів; перекриття доступу терористам до фінансів; мінімізація наслідків терористичних

\footnotetext{
15 Terrorism in Europe. Statistics \& Facts. URL: https://www.statista.com/topics/3788/terrorism-in-europe (дата звернення: 01.11.2020). URL: https://www.statista.com/topics/3788/terrorism-in-europe (дата звернення: 01.11.2020).
} 
актів ${ }^{16}$. Однак у 2015 р. система заходів зазнала корегування, у зв'язку з чим на основі попередньої стратегії було прийнято «Свропейський порядок денний з безпеки», який продовжив реалізацію послідовних $\mathrm{i}$ безперервних дій у процесі запобігання терористичним актам. Ця стратегія охопила якомога більше сторін різноманітної терористичної діяльності, зосередивши дії на максимальному позбавленні доступу терористів до фінансів, ресурсів і засобів для вчинення терористичних актів, посиленні захисту і підвищенні стійкості до терористичної загрози, попередженні радикалізації та унеможливленні поширення терористичної пропаганди через 3МІ й Інтернет-ресурси ${ }^{17}$.

Не зупиняючись на цьому, у 2017 p. Свропейський Союз приймає Директиву про боротьбу з тероризмом. Директива підсилює правову базу, оскільки вона більш повно охоплює дії, пов'язані з тероризмом. У межах Директиви усі держави-члени СС гарантують те, що вони будуть вводити криміналізацію усіх дій, пов'язаних із поїздками в іншу країну з метою вчинення терористичного злочину або для проведення чи проходження навчання тероризму. Закріплене значно сприяло узгодженню дій між країнамичленами Союзу, що служить орієнтиром для співпраці й обміну інформацією між національними властями. У процесі протидії Директива проявила себе задовільно, істотно зміцнивши підхід кримінального правосуддя державчленів до тероризму та прав жертв, які постраждали від нього ${ }^{18}$.

Важливим кроком на шляху запобігання терористичним актам у великих містах країн-членів $Є С$ є прийняття у 2020 р. Європейською комісією нової Стратегії безпеки СС на період із 2020 по 2025 рр. Стратегія фокусується на пріоритетних напрямах, покликаних забезпечити безпечне середовище, що відповідає вимогам завтрашнього дня, встановлюючи підхід для ефективного та скоординованого реагування на мінливі ландшафти загроз. Одним із цих пріоритетних напрямів Стратегії є «Захист європейців від тероризму та організованої злочинності». Ключовими діями, які описані у Стратегії та забезпечують громадську безпеку та правопорядок від терористичних актів, $\epsilon$ :

- по-перше, захист громадських місць. Свропейська комісія, а також регіональні та місцеві органи влади посідають головне місце у підвищенні безпеки громадських місць. Запуск нового партнерства по безпеці

\footnotetext{
${ }^{16}$ EU Counter Terrorism Strategy 2005. URL: https://ec.europa.eu/home-affairs/what-we-do/policies/counterterrorism_en (дата звернення: 03.11.2020).

${ }^{17}$ Communication from the commission to the European parliament, the Council, the European economic and social committee and committee of the regions. URL: https://ec.europa.eu/home-affairs/sites/homeaffairs/files/ e-library/documents/ basic-documents/docs/eu_agenda_on_security_en.pdf (дата звернення: 07.11.2020).

${ }^{18}$ Directive (EU) 2017/541 of the European Parliament and of the Council of 15 March 2017 on combating terrorism and replacing Council Framework Decision 2002/475/JHA and amending Council Decision 2005/671/JHA. URL: https://eur-lex.europa.eu/legal-content/EN/TXT/?uri=CELEX:32017L0541 (дата звернення: 12.11.2020).
} 
у громадських місцях, яка має назву «Urban Agenda», відображає намір держав-членів, комісії та міст більш ефективно протидіяти загрозам безпеки у міському просторі. До заходів, які сприятимуть захисту громадських місць, належать: діяльність правоохоронних органів, встановлення адекватних систем виявлення підозрілих осіб, не порушуючи свободи громадян, і контроль за безпілотними літальними апаратами (квадрокоптерами, дронами). Особлива увага приділяється контролю за безпілотними літальними апаратами, оскільки вони стають дедалі доступнішими та більш функціональними. Використання терористами безпілотних літальних апаратів у вчиненні своїх злочинних дій може привести до приведення громадських місць у стан особливою загрози. 3 урахуванням цього Європейським агентством із безпеки польотів зроблено перший крок у врегулюванні цього питання - реєстрацію операторів безпілотних літальних апаратів та обов'язкової дистанційної ідентифікації таких апаратів;

- по-друге, приведення у відповідну безпеку онлайн-середовище, тобто протидіяти незаконному контенту в Інтернеті шляхом налагодженого співробітництва між правоохоронними органами та приватним сектором у рамках Інтернет-форуму $\mathrm{CC}$, що дозволить попередити неправомірне використання мережі Інтернет терористами;

- по-третє, обмеження доступу до окремих хімічних речовин, які можуть бути використані для незаконного виготовлення саморобних вибухових речовин, котрі можуть бути застосовані під час вчинення терористичних актів. Для врегулювання цього моменту СС розробило найбільш передове у світі законодавство для обмеження доступу до прекурсорів вибухових речовин, а також виявлення підозрілих дій, спрямованих на створення самодільних вибухових речовин;

- по-четверте, ефективне переслідування тих осіб, які перебувають у розшуку за скоєння терористичного акту, в т. ч. бойовиків-іноземців, які перебувають у Сирії та Іраку, з метою недопущення продовження ними терористичної діяльності;

- по-п’яте, викорінення джерел фінансування терористичних актів. 3 огляду на те, що терористи та їхні пособники постійно змінюють способи збору, переміщення й отримання доступу до фінансів, ЄС регулярно оновлює інструменти та заходи для виявлення, запобігання, відстеження та припинення цієї діяльності. Ними було розроблено широкий спектр заходів боротьби з фінансуванням тероризму, включаючи оновлену Директиву про боротьбу 3 відмиванням грошей, яка ввела посилені заходи щодо запобігання фінансування тероризму, тим самим зміцнила потенціал правоохоронних органів у цій галузі шляхом покращення їх доступу до фінансової інформації; 
- по-шосте, безупинне продовження співробітництва 3 передовими суб'єктами протидії терористичним актам: ООН, НАТО, Радою Свропи, Інтерполом та ОБС ${ }^{19}$.

Основним органом, що відповідає за запобігання терористичним актам у Європі, є Європейське поліцейське управління (далі - Європол). Комплектація Сврополу у 2020 р. значно збільшилася, підвищено бюджет і чисельність штату співробітників у зв'язку 3 викликами недавніх хвиль терористичних актів ${ }^{20}$. Так, бюджет Європолу у 2020 р. становить 155 млн євро, а його штат налічує майже 1300 осіб, що майже вдвічі більше, ніж було десять років тому. Зростаючі зусилля по запобіганню та боротьбі з терористичними актами зумовили збільшення кількості арештів за готування та вчинення терористичних актів, наприклад, у 2015 р. було заарештовано 1077 осіб, у 2016 p. - 1002 , у 2017 p. - 1219 , у 2018 р. 1056 осіб, у 2019 p. -1004 особи.

Кінцева мета діяльності співробітників Європолу полягає в порятунку життів і мінімізації числа жертв. Враховуючи ці пріоритетні напрями, вони мотивовані підтримувати держав-членів ЄС і партнерів Сврополу у протидії терористичним актам ${ }^{21}$.

Яскравим прикладом запобігання терористичним актам у великих містах виявилася система заходів, які діють у Франції. Великі міста Франції значно потерпіли від терористичних актів, тут протягом останніх років були вчинені найбільш страшні 3 огляду на кількість загиблих теракти. Прикладом є терористичний акт 2015 р., коли у Парижі були вчинені одночасно декілька терористичних актів: вибухи біля стадіону, розстріл відвідувачів ресторанів, напад у концертному залі, внаслідок чого терористи позбавили життя 130 осіб $^{22}$, і теракт у 2016 р. в місті Ніцца, під час якого вантажний автомобіль із терористом протаранив натовп людей iз терористичною метою, внаслідок чого загинули 86 осіб ${ }^{23}$. Однак Франція у своїй діяльності систематично поліпшує та зміцнюе інструменти запобігання терористичним актам, які знаходяться в розпорядженні ЄС.

\footnotetext{
${ }^{19}$ Communication from the commission to the European parliament, the Council, the European economic and social committee and committee of the regions. URL: https://ec.europa.eu/home-affairs/sites/homeaffairs/files/elibrary/documents/basic-documents/docs/eu_agenda_on_security_en.pdf (дата звернення: 07.11.2020).

${ }^{20}$ Obokata T. Policies and Programmes under Mastricht Treaty. Trafficking of Human Beings from a Human Rights Perspective: Towards a Holistic Approach. Leiden, Boston : Martinus Nijhoff Publishers. 2006. P. 90 (дата звернення: 14.11.2020).

${ }^{21}$ Terrorism in Europe. Statistics \& Facts. URL: https://www.statista.com/topics/3788/terrorism-in-europe (дата звернення: 01.11.2020).

${ }^{22}$ Phipps C. Paris attacker named as Ismaïl Omar Mostefai as investigation continues - live updates. URL: https://www.theguardian.com/world/ live/2015/nov/15/paris-attacker-named-investigation-continues-live-updates (дата звернення: 07.11.2020).

${ }^{23}$ Теракт в Ницце: погибли граждане восьми стран. URL: https://korrespondent.net/world/3717820-teraktv-nytstse-pohybly-hrazhdane-vosmy-stran (дата звернення: 16.11.2020).
} 
Франція та тї партнери досягли значних успіхів у сфері запобігання терористичним актам: вони створили європейську систему реєстрації імен пасажирів авіарейсів, яка сприяє кращому контролю міжнародних i місцевих авіаційних перельотів; зміцнили співпрацю із цифровими платформами в рамках Інтернет-форуму СС для запобігання використання Інтернету в терористичних цілях; мобілізували європейські інструменти замороження й арешту фінансових активів, необхідних терористам; посилили заходи протидії торгівлі зброєю; встановили нові правила запобігання фінансування терористичних актів і відмивання грошей; посилили діяльність Європолу та його контртерористичного центру ${ }^{24}$.

Отже, Європейський Союз продовжує створювати нові інструменти для підтримки безпеки європейського суспільства та стратегічно важливих об'єктів інфраструктури від терористичних актів. Як бачимо, у процесі запобігання терористичним актам у країнах-членах Свропейського Союзу задіяно широке коло державних, приватних i недержавних суб'єктів, діяльність яких направлена на запобігання терористичним актам із використанням хімічних, біологічних, радіологічних і ядерних матеріалів, захист громадських місць, обмеження доступу осіб до безпілотних літаючих об'єктів, контроль обігу вибухових речовин і прекурсорів вибухових речовин, викорінення джерел фінансування терористичних актів, а також подальше співробітництво з передовими організаціями. Вважаємо, що такі заходи, які використовує у запобіжній діяльності Європейський Союз, стануть підгрунтям для вдосконалення вітчизняної системи запобігання терористичним актам у великих містах, 3 огляду на те, що українська держава перебуває у постійному пошуку найбільш ефективних заходів запобігання цьому суспільно небезпечному явищу.

\section{ВИСНОВКИ}

Таким чином, досвід високорозвинених країн світу у запобіганні терористичним актам у державі загалом і у великих містах зокрема вміщує в собі найбільш ефективні та всебічно виважені заходи. Аналіз досвіду США та держав-членів Європейського Союзу дозволив виокремити позитивний досвід представлених держав у втіленні на практиці заходів запобігання терористичним актам. На нашу думку, міжнародний досвід США та держав-членів СС у запобіганні терористичним актам у великих містах може стати інструментом, який дасть можливість Україні побудувати надійну, ефективну та діючу конструкцію запобігання цьому суспільно

\footnotetext{
${ }^{24}$ Terrorism: France's International Action. URL: https://www.diplomatie./gouv.fr/en/french-foreign-policy/ security-disarmament-and-noproliferation/terrorism-france-s-internationalaction (дата звернення: 16.11.2020).
} 
небезпечному злочинному явищу i, як наслідок, створити середовище, безпечне для мирного населення та несприятливе для терористів.

Досвід США для вітчизняної системи запобігання терористичним актам сприятиме: оперативному та якісному попередженню терористичних актів; налагодженню роботи між компетентними органами; унеможливленню застосування зброї масового ураження під час вчинення терористичних актів; забороні надавати допомогу терористам; забороні фінансувати терористичні акти; перешкоджанню терористам у контролюванні великих міст; укріпленню громадянської позиції нетерпимості до готування та вчинення терактів; налагодженню партнерських відносин з іншими державами.

Досвід держав-членів Європейського Союзу для вітчизняної системи запобігання терористичним актам сприятиме: кращому контролю міжнародних і місцевих авіаційних перельотів; надійному захисту громадських місць; здійсненню контролю й обмеженню доступу до безпілотних літальних апаратів; зміцненню співпраці 3 цифровими платформами для запобігання використання Інтернету в терористичних цілях; унеможливленню терористичної пропаганди; посиленню заходів протидії торгівлі зброєю; обмеженню доступу до окремих хімічних речовин, які можуть слугувати прекурсором для саморобних вибухових пристроїв.

\section{АНОТАЦІЯ}

Терористичні акти у великих містах країн світу становлять загрозу для усіх сфер життєдіяльності суспільства, завдають шкоду громадській безпеці, підривають імідж правоохоронних органів і підсилюють рівень напруги у суспільстві. Значними досягненнями у сфері запобігання терористичним актам у великих містах відзначилися США та держави-члени Свропейського Союзу. Представлені країни мають стабільну правову систему, достатньо високу економічну розвиненість і вагому базу напрацювань усфері запобігання терористичним актам у великих містах. США та держави-члени $\mathrm{CC}$ спрямовують значні зусилля на пошук нових i досконалих підходів запобігання терористичним актам. Система запобігання терористичним актам у великих містах США характеризується великим штатом професійних фахівців, значними надбаннями у розвідувальній та оперативній діяльності, що сприяє якісному попередженню цього злочину. Держави-члени ЄС у процесі проведення запобіжної діяльності продовжують створювати нові інструменти для підтримки безпеки європейського суспільства та стратегічно важливих об'єктів інфраструктури від терористичних актів. Запозичення досвіду цих держав сприятиме побудуванню надійної, ефективної та діючої конструкції запобігання терористичним актам у великих містах України. 


\section{ЛIТЕРАТУРА}

1. Global Terrorism Index 2016. Institute for Economics \& Peace. URL: https://www.economicsandpeace.org/wp/content/uploads/2016/11/GlobalTerrorism-Index-2016.2.pdf (дата звернення: 30.10.2020).

2. Global Terrorism Index 2019. Institute for Economics \& Peace. URL: https://www.economicsandpeace.org/wp-content/uploads/2020/08/ GTI-2019web.pdf (дата звернення: 30.10.2020).

3. The Escalating Terrorism Problem in the United States. Center for strategic \& International studies. 2020. URL: https://www.csis.org/analysis/escalatingterrorism-problem-united-states (дата звернення: 08.11.2020).

4. National Strategy for Counterterrorism of the United States of America. URL: https: //www.whitehouse.gov/wp-content/uploads/2018/10/NSCT.pdf (дата звернення: 09.11.2020).

5. National Prevention Framework. Second Edition. URL: https://www.fema.gov/medialibrarydata/146601720927983b72d5959787995794 c08/74095500b1/National_Prevention_Framework2nd.pdf (дата звернення: 10.11.2020).

6. Terrorism 2002-2005. U.S. Department of Justice Federal Bureau of Investigation. 2005. URL: https://www.fbi.gov/stats-services/publications/ terrorism-2002-2005 (дата звернення: 10.11.2020).

7. Інформація з офіційного сайту ФБР. URL: https://www.fbi.gov/investiga/ te/terrorism (дата звернення: 10.11.2020).

8. Мокляк В.В. Сучасний досвід США у сфері запобігання тероризму. Питання боротьби зі злочинністю. 2017. № 34. С. 219-229. URL: http://nbuv.gov.ua/UJRN/Pbzz_2017_34_20 (дата звернення: 10.11.2020).

9. Terrorism in Europe. Statistics \& Facts. URL: https://www.statista.com/ topics/3788/terrorism-in-europe (дата звернення: 01.11.2020).

10. EU Counter Terrorism Strategy 2005. URL: https://ec.europa.eu/homeaffairs/what-we-do/policies/counter-terrorism_en (дата звернення: 03.11.2020).

11. Communication from the commission to the European parliament, the Council, the European economic and social committee and committee of the regions. URL: https://ec.europa.eu/home-affairs/sites/homeaffairs/files/ e-library/documents/basic-documents/docs/eu_agenda_on_security_en.pdf (дата звернення: 07.11.2020).

12. Directive (EU) $2017 / 541$ of the European Parliament and of the Council of 15 March 2017 on combating terrorism and replacing Council Framework Decision 2002/475/JHA and amending Council Decision 2005/671/JHA. URL: https://eur-lex.europa.eu/legal-content/EN/TXT/?uri=CELEX:32017L0541 (дата звернення: 12.11.2020). 
13. Communication from the commission on the EU Security Union Strategy. URL: https://eurlex.europa.eu/legalcontent/EN/TXT/?qid=1596452256370\&uri= CELEX: 52020DC0605 (дата звернення: 12.11.2020).

14. Obokata T. Policies and Programmes under Maastricht Treaty. Trafficking of Human Beings from a Human Rights Perspective: Towards a Holistic Approach. Leiden, Boston : Martinus Nijhoff Publishers, 2006. P. 90 (дата звернення: 14.11.2020).

15. Phipps C. Paris attacker named as Ismaïl Omar Mostefai as investigation continues - live updates. URL: https://www.theguardian.com/world/ live/ 2015/nov/15/paris-attacker-named-investigation-continues-live-updates (дата звернення: 07.11.2020).

16. Теракт в Ницце: погибли граждане восьми стран. URL: https://korrespondent.net/world/3717820-terakt-v-nytstse-pohybly-hrazhdanevosmy-stran (дата звернення: 16.11.2020).

17. Terrorism: France's International Action. URL: https://www.diplomatie./ gouv.fr/en/french-foreign-policy/security-disarmament-and-noproliferation/ terrorism-france-s-internationalaction (дата звернення: 16.11.2020).

\section{Information about authors: Stukalina O. V.,} Graduate Student at the Department of Criminal Law and Criminology Odesa State University of Internal Affairs 1, Uspenskaia str., Odesa, 65000, Ukraine

Kulik L. M., Candidate of Law, Associate Professor, Associate Professor at the Department of Criminal Law and Criminology Odesa State University of Internal Affairs 1, Uspenskaia str., Odesa, 65000, Ukraine 